\begin{tabular}{|c|c|c|c|c|}
\hline $\begin{array}{c}\text { Jurnal Penelitian \& } \\
\text { PPM }\end{array}$ & ISSN: 2442-448X & Vol 5, No: 1 & Hal: $1-110$ & April 2018 \\
\hline
\end{tabular}

\title{
PEMANFAATAN LEMBAGA LOKAL UNTUK PELAKSANAAN TERTIB ADMINISTRASI KEPENDUDUKAN DI DESA GENTENG
}

\author{
Oleh : \\ Nunung Nurwati ${ }^{1}$, Hetty Krisnani ${ }^{2}$, Agus Wahyudi Riana ${ }^{3}$, Eva Nuriyah Hidayat ${ }^{4}$, dan Sahadi Humaedi ${ }^{5}$. \\ 1. Dosen IImu Kesejahteraan Sosial, Fakultas IImu Sosial Dan IImu Politik, Universitas Padjadjaran \\ 2. Dosen IImu Kesejahteraan Sosial, Fakultas IImu Sosial Dan IImu Politik, Universitas Padjadjaran \\ 3. Dosen IImu Kesejahteraan Sosial, Fakultas IImu Sosial Dan IImu Politik, Universitas Padjadjaran \\ 4. Dosen IImu Kesejahteraan Sosial, Fakultas IImu Sosial Dan IImu Politik, Universitas Padjadjaran \\ 5. Dosen Ilmu Kesejahteraan Sosial, Fakultas IImu Sosial Dan Ilmu Politik, Universitas Padjadjaran \\ Email: \\ nngnurwati@unpad.ac.id, hettykrisnani@yahoo.com, enuriyah@yahoo.co.id, aguswahyudiriana@yahoo.com \\ sahadihumaedi@yahoo.com
}

\begin{abstract}
ABSTRAK
Kegiatan PKM dengan judul "Pemanfaatan Lembaga Lokal Untuk Pelaksanaan Tertib Administrasi Kependudukan Di Desa Genteng“, bertujuan untuk memanfaatkan keberadaan lembaga lokal yang ada untuk pelaksanaan pelaksanaan pendataan kependudukan sehingga dapat menciptakan tertib administrasi kependudukan. Untuk mencapai maksud tersebut, Tim PKM telah melaksanakan kegiatan berupa pelatihan dengan materi-materi mencakup peraturan dan teknis registrasi penduduk. Pelatihan ini dilaksanakan di Desa Genteng, dihadiri oleh 45 peserta, terdiri dari ketua RW, Ketua RT, kader posyandu, dan PKK. Pelatihan difokuskan pada materi Registrasi penduduk sebagai berikut: 1) Undang-undang No. 23 Tahun 2006 tentang Administrasi Kependudukan; dan 2) Teknis Pengisian Data Kependudukan. Untuk menilai tingkat keberhasilan kegiatan pelatihan digunakan alat bantu berupa Pre-Test dan Post-Test. Hasil dari kegiatan pelatihan pemanfaatan lembaga lokal dalam pelaksanaan registrasi penduduk ini baru mencapai pada aspek kognitif dan afeksi, hal ini dapat terlihat dari kemampuan peserta dalam memahami materi yang disampaikan oleh pemateri. Selain itu, tingkat partisipasi peserta dalam kegiatan diskusi pemecahan masalah cukup baik, hal ini dapat terlihat saat kegiatan tersebut dilaksanakan.
\end{abstract}

Kata kunci: Lembaga lokal, Pelatihan administrasi kependudukan

\section{Pendahuluan}

Desa Genteng merupakan salah satu desa di Kecamatan Sukasari, Kabupaten Sumedang, Desa Genteng ini adalah salah satu lokasi kegiatan assessment himpunan mahasiswa yang bekerjasama dengan prodi dalam kegiatan bina desa yang dilaksanakan rutin setiap tahun selama 1 minggu di bulan November 2016. Berdasarkan hasil assessment tersebut menunjukan bahwa aparat pemerintahan desa dan lembaga lokal dianggap sebagai ujung tombak dalam pengisian data kependudukan dan data kependudukan tersebut akan dapat digunakan sebagai landasan penyusunan program-program pemerintah, baik pemerintah daerah maupun pemerintah pusat.

Data hasil registrasi banyak memuat informasi kependudukan yang sangat berguna bagi perencanaan pembangunan di bidang ekonomi, pendidikan, kesehatan maupun sosial budaya. Jika perencanaan tersebut tidak didukung oleh data yang akurat maka capaian pembangunan kurang optimal bahkan tidak tepat sasaran.

Dari data hasil registrasi dapat digunakan untuk membuat peta potensi penduduk di antaranya berdasarkan struktur umur, mata pencaharian, migran atau non migran. Seharusnya pemanfaat ini harus sudah dimulai 
dari tingkat daerah hingga pusat. Namun pemanfaatan data tersebut hingga saat ini masih kurang. Untuk itu, perlu adanya pemanfaatan lembaga lokal untuk pelaksanaan tertib administrasi kependudukan, guna membantu aparat desa. Sasaran dari kegiatan ini adalah lembaga-lembaga lokal di tingkat desa, yang dapat membantu aparat desa yang merupakan "pos terdepan” dalam kegiatan pencatatan dan pelaporan.

\section{Pembahasan}

Pada tahun sebelumnya yaitu tahun 2016, Ketua Tim PPM telah melakukan kegitan pengabdian dengan judul Pelatihan Pemanfaatan Data Hasil Registrasi Penduduk Bagi Pamong Desa di Desa Genteng, Kecamatan Sukasari, Kabupaten Sumedang. Sebagai tindak lanjut dari kegiatan pengabdian yang telah dilakukan pada tahun sebelumnya, maka pada tahun 2017 ini Ketua Tim PPM kembali menginisiasi kegiatan pengabdian di lokasi yang sama. Tema dalam kegiatan pengabdian pada tahun ini yaitu Pemanfaatan Lembaga Lokal Untuk Pelaksanaan Tertib Administrasi Kependudukan di Desa Genteng Kec. Sukasari, Kab. Sumedang.

Program Pemanfaatan Lembaga Lokal untuk Pelaksanaan Tertib Administrasi Kependudukan di Desa Genteng Kec. Sukasari, Kab. Sumedang dilaksanakan dengan metode workshop yang mendatangkan tenaga ahli dalam bidang ini. Sasaran dari kegiatan ini adalah penduduk di Desa Genteng sendiri dengan para petugas kependudukan di Desa Genteng.

Kegiatan ini dilaksanakan sekitar pukul 13.00 WIB di aula balai Desa Genteng. Penyuluhan ini disampaikan oleh seorang narasumber yang merupakan dosen dari Program Studi Kesejahteraan Sosial, Fakultas Ilmu Sosial dan Ilmu Politik, Universitas Padjadjaran. Peserta workshop berjumlah kurang lebih 35 orang. Sebelum ke materi, peserta melakukan pre test terlebih dahulu. Lalu setelah dilakukan pre test peserta diberikan materi penyuluhan. Materi penyuluhan ini diawali dengan materi pengenalan dokumen kependudukan, seperti biodata penduduk, kartu keluarga, akta kelahiran, Kartu Tanda Penduduk, dan surat keterangan kependudukan.

Selanjutnya adalah penyampaian materi dan berdiskusi lagsung dengan peserta. Ada beberapa masalah yang didapat ketika warga mengeluarkan suaranya saat sesi diskusi berlangsung. Warga masih ada yang belum memiliki Kartu Kelurga, alasannya adalah membuat Kartu Keluarga hanya untuk peminjaman

Bank. Selain itu juga karena harus bayar Rp. 250.000 serta adanya anggapan Kartu Keluarga masa berlakunya akan sebentar sehingga akan kadaluarsa. Menanggapi hal tersebut, narasumber menyarankan peserta untuk konsultasi ke Kecamatan bagian dinas kependudukan dikarenakan tidak ada pungutan biaya dari pemerintah juga Kartu Keluarga tidak ada kadaluarsa.

Keluhan masyarakat mengenai administrasi lainnya adalah menurut warga, data tidak otentik. Misalnya sudah ada data tentang warga yang meninggal. Namun untuk pemilu/pilpres namanya muncul lagi-muncul lagi. Permasalahan selanjutnya adalah masyarakat yang menerima bantuan seperti PKH dan KIS, datanya tidak diketahui oleh RT/RW. Sehingga masyarakat yang seharusnya menerima, malah tidak menerima. Menanggapi berbagai permasalahan tersebut, narasumber berpendapat bahwa hal tersebut sering terjadi dikarenakan data yang digunakan tidak update. Oleh karenanya, melalui pelatihan ini, masyarakat ikut mengontrol terhadap data kependudukan.

Lembaga lokal yang terdapat di Desa Genteng, diantaranya: 1) Karang Taruna; 2) PKK; 3) kelompok arisan; 4) kelompok pengajian; 5) Remaja Mesjid; 6) Bina Keluarga; dan 7) Bina Remaja.

Masyarakat diharapkan dapat berperan dalam administrasi kependudukan dengan melakukan beberapa hal berikut ini, antara lain: a) membantu petugas di lingkungannya secara langsung maupun tidak langsung; b) aktif mendata anggota kelompoknya; c) sebagai kontrol sosial di lingkungannya; dan d) 
memberi penyuluhan terkait laporan peristiwa kependudukan

Selanjutnya narasumber memberikan contoh kasus terkait kependudukan untuk diskusi bersama. Diskusi tersebut berjalan dengan lancar dan pserta juga interaktif.

Rencana keberlanjutan program dalam kegiatan ini adalah peningkatan kapasitas pamong dan lembaga lokal dalam pemanfaatan data kependudukan untuk kepentingan program pembangunan desa.

Untuk mengetahui keberhasilan dari kegiatan PPM ini digunakan instrumen pre test dan post test berupa lembar angket yang akan diberikan sebelum dan sesudah kegiatan pelatihan PPM. Sementara Monitoring akan dilakukan pada saat kegiatan pencatatan formulir/blangko registrasi penduduk, serta pemanfaatan data di desa untuk melihat partisipasi lembaga lokal dalam kegiatan tersebut.

\section{Simpulan}

Di Desa Genteng, pelaporan peristiwa kependudukan kepada petugas registrasi dilakukan oleh anggota keluarga (pelaku sendiri) maka pelaksanaannya sangat tergantung kepada kesadaran anggota masyarakat tentang penting dan manfaat pencatatan kependudukan bagi kepentingan pembangunan daerah maupun dirinya sendiri. Oleh karena itu, masyarakat Desa Genteng diberikan pelatihan mengenai Tertib Administrasi.

Setelah mengikuti pelatihan/workshop yang telah dilaksanakan mengenai tertib administrasi, masyarakat diharapkan dapat berperan aktif dalam administrasi kependudukan, diantaranya: 1) membantu petugas di lingkungannya baik secara langsung maupun tidak langsung; 2) aktif mendata anggota kelompoknya; 3) sebagai kontrol sosial di lingkungannya; 4) memberi penyuluhan terkait laporan peristiwa kependudukan; 5) memiliki dokumen kependudukan karena sangat penting.

\section{Daftar Pustaka}

Adi.Isbandi Rukminto. 2008. Intervensi Komunitas Pengembangan Masyarakat Sebagai Upaya Pemberdayaan Masyarakat. Jakarta: Rajawali Pers

Cary, Lee. 1970. Community Development As A Process. Missouri. Univerity of Missouri Press.

Hikmat, Harry. 2006. Strategi Pemberdayaan Masyarakat. Bandung : Humaniora Utama Press.

Ife, Jim. 2008. Community Development : Alternatif Pengembangan Masyarakat di Era Globalisasi. Jogjakarta. Pustaka Pelajar.

Kartasasmita, Ginandjar. 1996. Pembangunan untuk rakyat: memadukan pertumbuhan dan pemerataan. Jakarta. CIDES

Lewis, Judith A., 1991, Management of Human Services Programs. California Brooks/Cole Publishing Company

Parsons, Ruth J., James D. Jorgensen, Santos H. Hernandez, 1994. The Integration of Social Work Practice. Wadsworth, Inc., California.

Raharjo, ST (ed). (2016). Kerentanan dan Disabilitas, Kumpulan Tulisan. Bandung: Unpad Press.

Raharjo, ST .(2015). Pekerjaan Sosial Generalis, Pengantar Bekerja Bersama Organisasi dan Komunitas. Bandung: Unpad Press.

Rappaport, J., 1984. Studies in Empowerment: Introduction to the Issue, Prevention In Human Issue. USA.

Rencana Pembangunan Jangka Menengah Desa 2011-2015. Desa Genteng, Kecamatan Sukasari, Kabupaten Sumedang. 2011.

Suharto. Edi.1997.Pembangunan, Kebijakan Sosial, dan Pekerjaan Sosial. Bandung: LSPSTKS 


\begin{tabular}{|c|c|c|c|c|}
\hline $\begin{array}{c}\text { Jurnal Penelitian \& } \\
\text { PPM }\end{array}$ & ISSN: 2442-448X & Vol 5, No: 1 & Hal: 1 - 110 & April 2018 \\
\hline
\end{tabular}

Wibhawa, B., Raharjo, ST., \& Santoso, MB.

2010. Dasar Dasar Pekerjaan Sosial. Widya

Padjadjaran: Bandung 